\title{
Nur 2 r? Carboniferous and Permian history of the Wandel Sea Basin, North Greenland
}

\author{
Lars Stemmerik and Eckart Håkansson
}

\begin{abstract}
Upper Palaeozoic sediments in North Greenland were deposited in basins formed as the result of rifting between Norway, Greenland and Svalbard. The succession comprises Upper Carboniferous fluviatile sediments, Upper Carboniferous mixed shallow marine siliciclastic sediments and carbonates, Lower Permian shallow water carbonates, and Upper Permian carbonates, cherts and shales. Major depositional sequences encompass the following intervals: early Moscovian, mid Moscovian Gzelian, Asselian-Kungurian, and Ufimian-Kazanian.

L. S., Geological Survey of Greenland, Øster Voldgade 10, DK-1350 Copenhagen K, Denmark.

E. H., Institute of Historical Geology and Palaeontology, University of Copenhagen, Øster Voldgade 10, DK-1350 Copenhagen K, Denmark.
\end{abstract}

Upper Palaeozoic sedimentary rocks in eastern areas of North Greenland (Fig. 1) were discovered by J. P. Koch and A. Wegener during the Danmarks Expedition of 1906-08. However, the remoteness of the area has severely restricted exploration and, until recently, knowledge of the Upper Palaeozoic succession has been confined largely to palaeontological and biostratigraphic accounts of the very limited material collected by J. P. Koch and A. Wegener in 1907, by E. Nielsen in 1938 , by J. C. Troelsen in 1948 and by W. E. Davies in 1961 (Nathorst, 1911; Grönwall, 1916; Frebold, 1950; Dunbar, 1962; Dunbar et al., 1962; Ross \& Dunbar, 1962; Ross \& Ross, 1962; Peel et al., 1974; BendixAlmgreen, 1975; Dawes, 1976; Petryk, 1977).

Upper Palaeozoic sediments throughout central and eastern North Greenland were investigated in some detail during 1978 and 1980 , as a part of the North Greenland Project of the Geological Survey of Greenland (Håkansson, 1979; Håkansson et al., 1981; see Henriksen \& Higgins, 1991). This work was followed recently by a more detailed study of the Upper Palaeozoic deposits on Prinsesse Ingeborg Halvø (Håkansson et al., 1989). The outcome of this recent work was not included in the lithostratigraphic frame-work established by Stemmerik \& Håkansson (1989).

The overall correlation of the Carboniferous and Permian deposits of Svalbard, the Sverdrup Basin of Arctic Canada and the Wandel Sea Basin of North Greenland is well established (Håkansson \& Stemmerik, 1984; Stemmerik \& Worsley, 1989; Davies \& Nassichuk, in press). However, looking in more detail, the most strik- ing depositional similarities are found between the successions on Svalbard and in the Sverdrup Basin (Davies \& Nassichuk, in press). This may reflect the fact that the limited exposures in Greenland include only the more shallow water parts of the shelf sequence.

\section{Geological setting and structural framework}

Upper Palaeozoic sedimentation post-dates the Caledonian orogenesis in eastern North Greenland and the Ellesmerian orogenesis in central North Greenland (Håkansson et al., 1981; Higgins et al., 1985; Hurst et al., 1985). Sedimentation reflects structural development in two different tectonic settings somewhat artificially united as the Wandel Sea Basin (Håkansson \& Stemmerik, 1989). It is suggested that deposition of Upper Palaeozoic sediments in Holm Land and Amdrup Land (Fig. 1) occurred in a basin developed as the result of rifting between Greenland and Norway (Fig. 2). Sediments exposed in eastern Peary Land and on Lockwood $\varnothing$ (Fig. 1) appear to have accumulated in a basin formed as the result of rifting between central North Greenland and Svalbard (Fig. 2). These two basins formed part of an extensive mosaic of interconnected basins covering the Barents Shelf region and the marginal areas of North Greenland during the Late Palaeozoic (Stemmerik \& Worsley, 1989).

Sedimentation was fairly uniform in the Wandel Sea Basin during Late Carboniferous and Early Permian times (Fig. 3). In the Holm Land area sedimentation started in the latest Devonian or earliest Carboniferous 


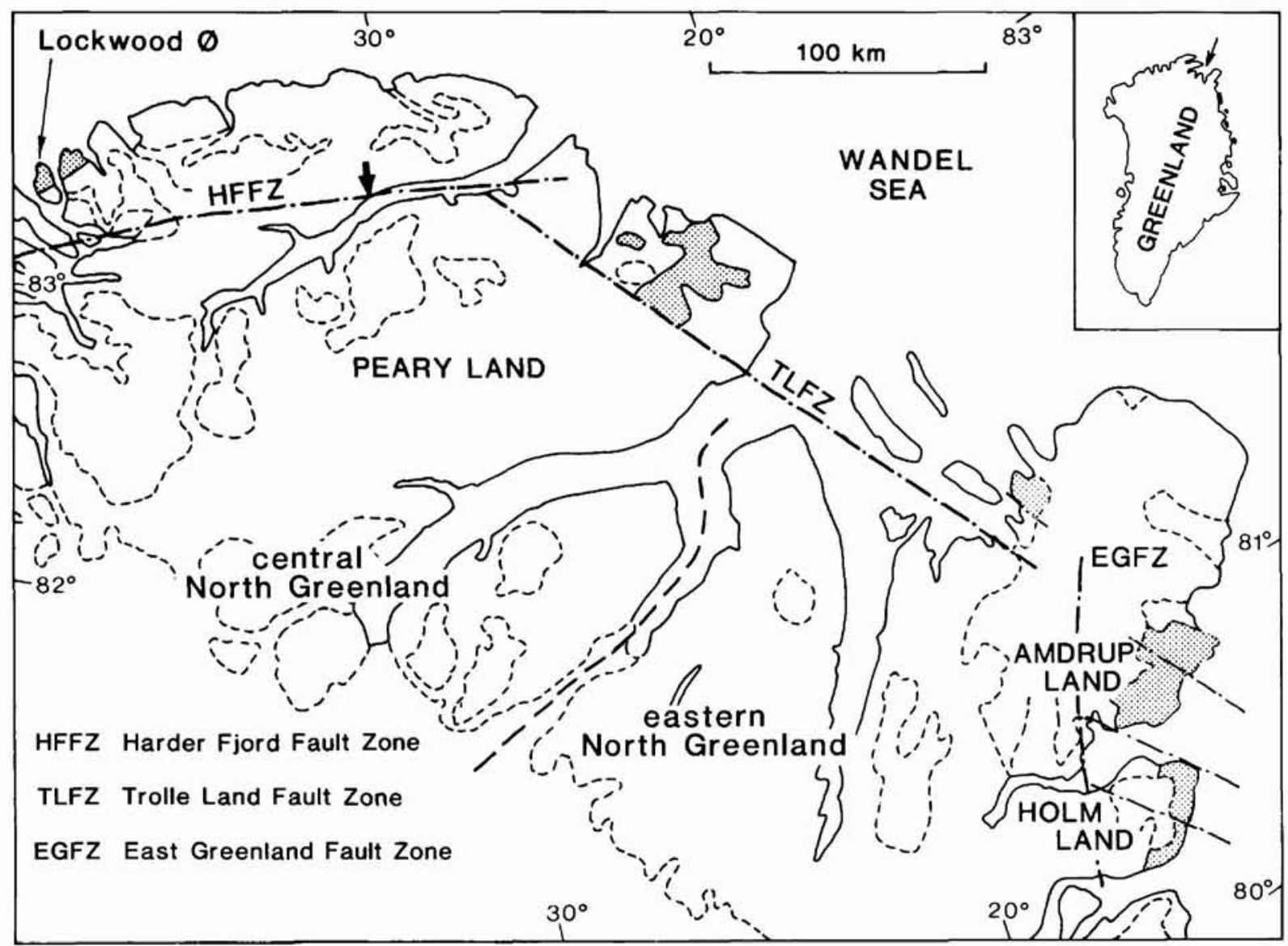

Fig. 1. Distribution of Upper Palaeozoic sediments (shaded) and major structural elements in central and eastern North Greenland. Arrow indicates a small outcrop of the Kap Kraka Formation.

and fluviatile sediments comparable to those in central East Greenland were deposited. The sediments were faulted and eroded, prior to the Late Carboniferous transgression, in a tectonic phase not recorded elsewhere in the area. Sedimentation continued north of the Trolle Land Fault Zone into the Late Permian in what appears to be a tectonically active basin. Similar conditions occur also in several of the basins in the Svalbard Barents Sea region (e.g. Stemmerik \& Worsley, 1989).

Upper Palaeozoic sediments in Holm Land and Amdrup Land rest directly on Precambrian basement, whereas the sediments in eastern Peary Land overlie a variety of strata deformed during the Ellesmerian Orogeny (Håkansson, 1979; Håkansson et al., 1981).

\section{Holm Land - Amdrup Land basin}

Upper Palaeozoic sediments in Holm Land and Amdrup Land were deposited during the initial stages of the rifting between Greenland and Norway. Rifting was initiated during latest Devonian or earliest Carboniferous time and is synchronous with, and related to, rifting events in Svalbard, the Barents Sea and central East Greenland (Stemmerik \& Worsley, 1989).

The main structural feature in Holm Land and Amdrup Land is the N-S trending East Greenland Fault Zone, considered to be the northern extension of the post-Devonian Main Fault Zone (Vischer, 1943) of central East Greenland (Fig. 2). Sedimentation was probably restricted to the subsiding areas east of this fault zone (Fig. 4). A series of NW-SE trending faults controlled the differential sedimentary history of a number of small fault blocks on this subsiding platform (Figs 1, 3).

A major tectonic event during mid-Carboniferous times disturbed the Lower Carboniferous sediments along N-S trending faults prior to the Late Carboniferous (early Moscovian) transgression (Håkansson et al., 1981; Håkansson \& Pedersen, 1982). 


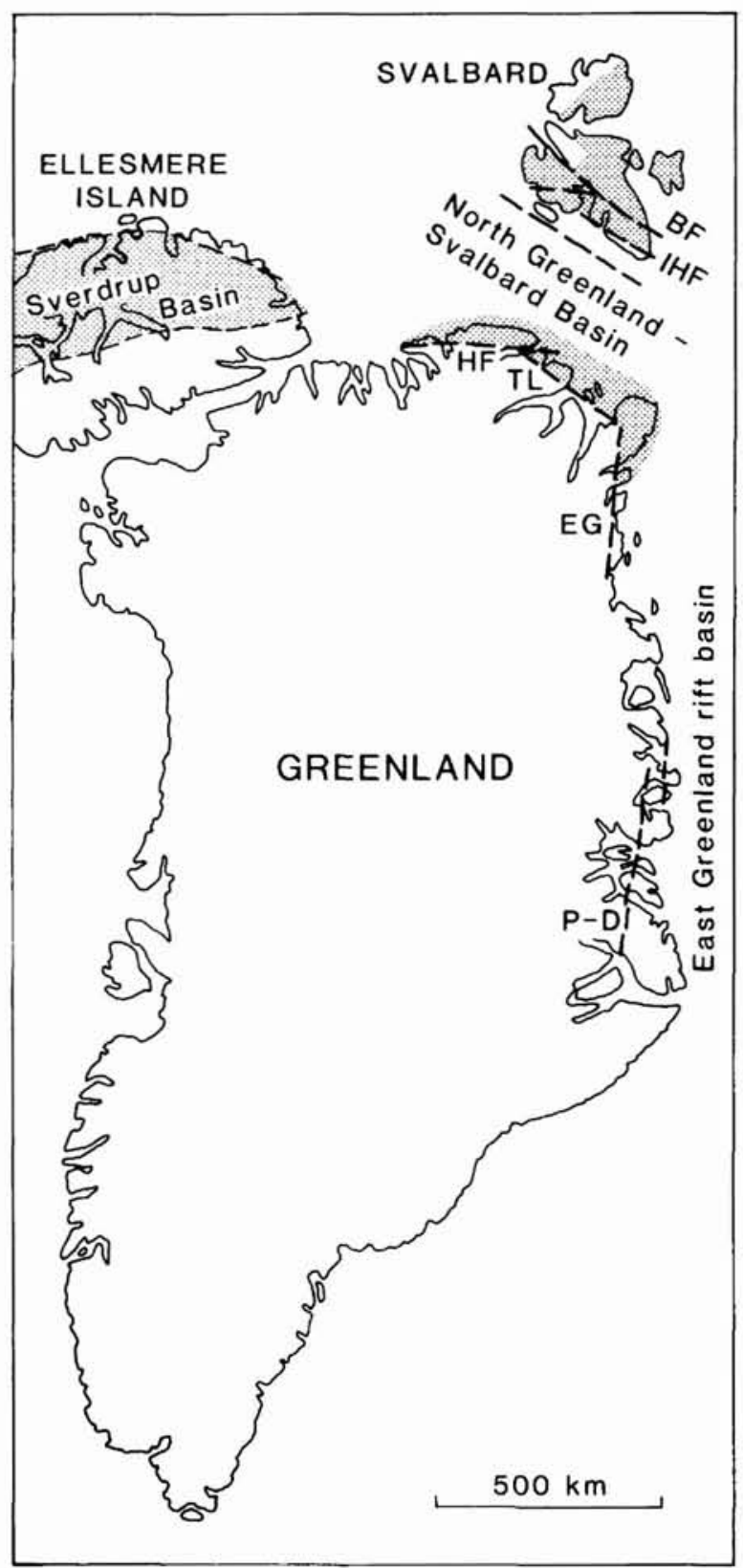

Fig. 2. General pre-drift configuration of Greenland, Svalbard and Ellesmere Island. The stippled area indicates the known extent of the Upper Palaeozoic basins. BF, Billefjorden Fault; IHF, Inner Hornsund Fault; HF, Harder Fjord Fault Zone; TL, Trolle Land Fault Zone; EG, East Greenland Fault Zone; P-D, post-Devonian Main Fault (based on Steel \& Worsley, 1984; Davies \& Nassichuk, in press; and various GGU maps).

\section{Peary Land - Prinsesse Ingeborg Halv $\varnothing$ basin}

Upper Carboniferous - Upper Permian sediments in Peary Land and Prinsesse Ingeborg Halvø are limited by the roughly E-W trending Harder Fjord Fault Zone and the NW-SE trending Trolle Land Fault Zone (Fig. 2). Favouring a pre-drift position of Svalbard north-east of Greenland (Fig. 2), these fault zones are roughly parallel to the fault-system which Steel \& Worsley (1984) consider to have controlled the Late Palaeozoic sedimentation in Svalbard. Thus, we suggest that during the Late Palaeozoic North Greenland constituted a fault-bound basin which was closely related to the basins found in Svalbard (Fig. 2).

The onset of sedimentation in this area during the Late Carboniferous may be structurally controlled. The following period was characterised by gentle subsidence of the basin and not until mid-Permian times is there evidence of renewed movements along the Harder Fjord and Trolle Land Fault Zones (Håkansson \& Pedersen, 1982; Nilsson et al., 1991). The Permian-Triassic boundary is marked by a low angle unconformity throughout the Arctic (Håkansson \& Stemmerik, 1984; Steel \& Worsley, 1984).

\section{Stratigraphy and lithofacies}

A stratigraphic scheme for the Lower Carboniferous to Upper Permian sediments in the Wandel Sea Basin has recently been proposed by Stemmerik \& Håkansson (1989). Correlation between the main outcrop areas, Holm Land - Amdrup Land and eastern Peary Land, is fairly well established for the Upper Carboniferous to lowermost Permian part of the succession (Fig. 3). However, the Permian part of the succession is not well dated and, accordingly, correlation is poor. These correlation problems have been substantiated further by the discovery of a thick Permian siliciclastic succession restricted to Prinsesse Ingeborg Halvø (Håkansson et al., 1989).

The succession in the Holm Land - Amdrup Land area has been investigated in greatest detail (Håkansson et al., 1981; Håkansson \& Stemmerik, 1984; Stemmerik, 1989a, b; Stemmerik \& Håkansson, 1989). Here outcrops can be followed for considerable distances along strike but, unfortunately, they only extend for a few kilometres E-W perpendicular to strike. As a result only a very limited cross-section is actually exposed. 

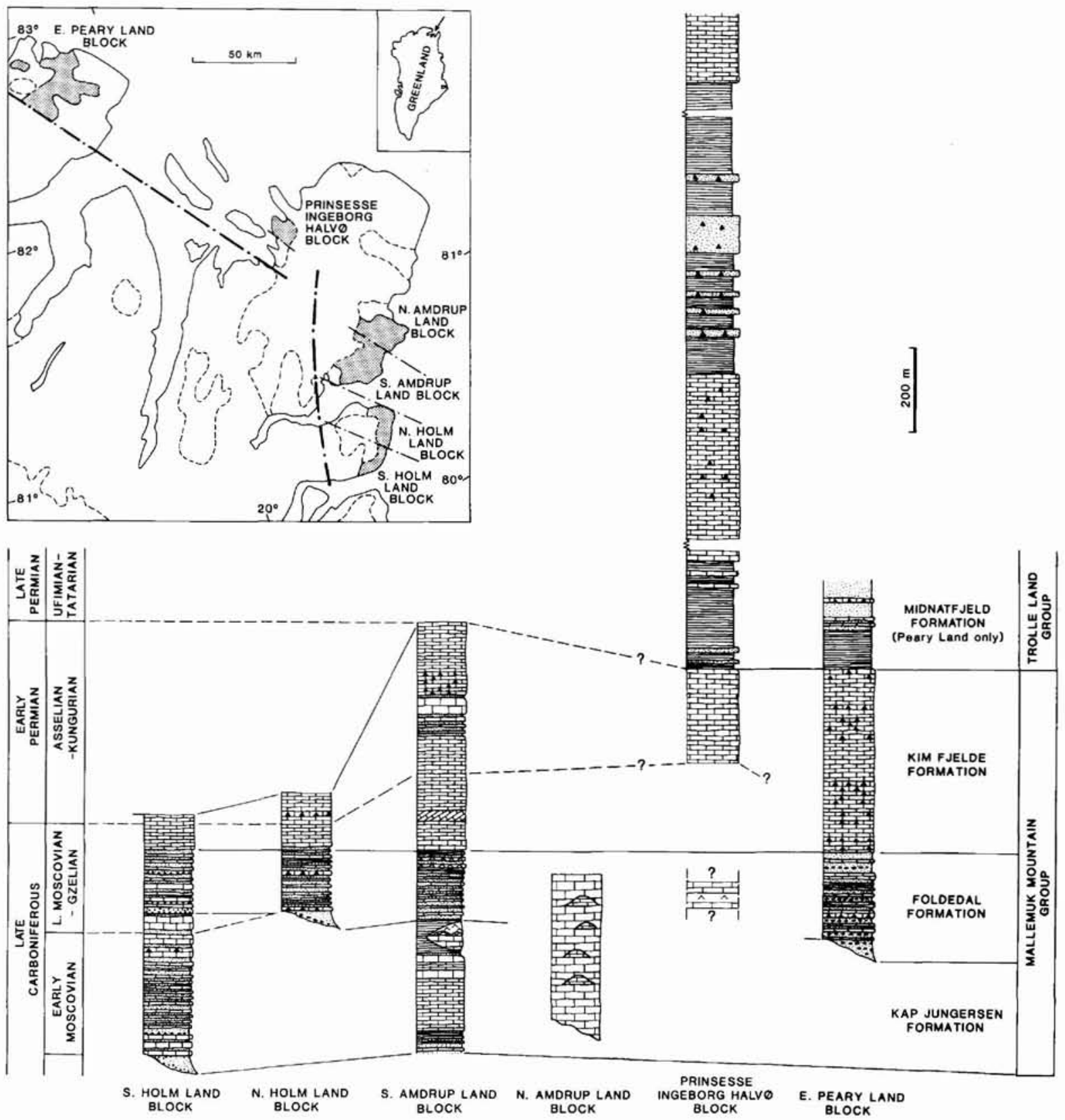

Fig. 3. Lithostratigraphic correlation of the marine Upper Palaeozoic sediments in eastern North Greenland. Solid lines indicate lithostratigraphic units; dotted lines are the proposed biostratigraphic correlation (based on Håkansson \& Stemmerik, 1984; Stemmerik \& Håkansson, 1989; Nilsson et al., 1991). 

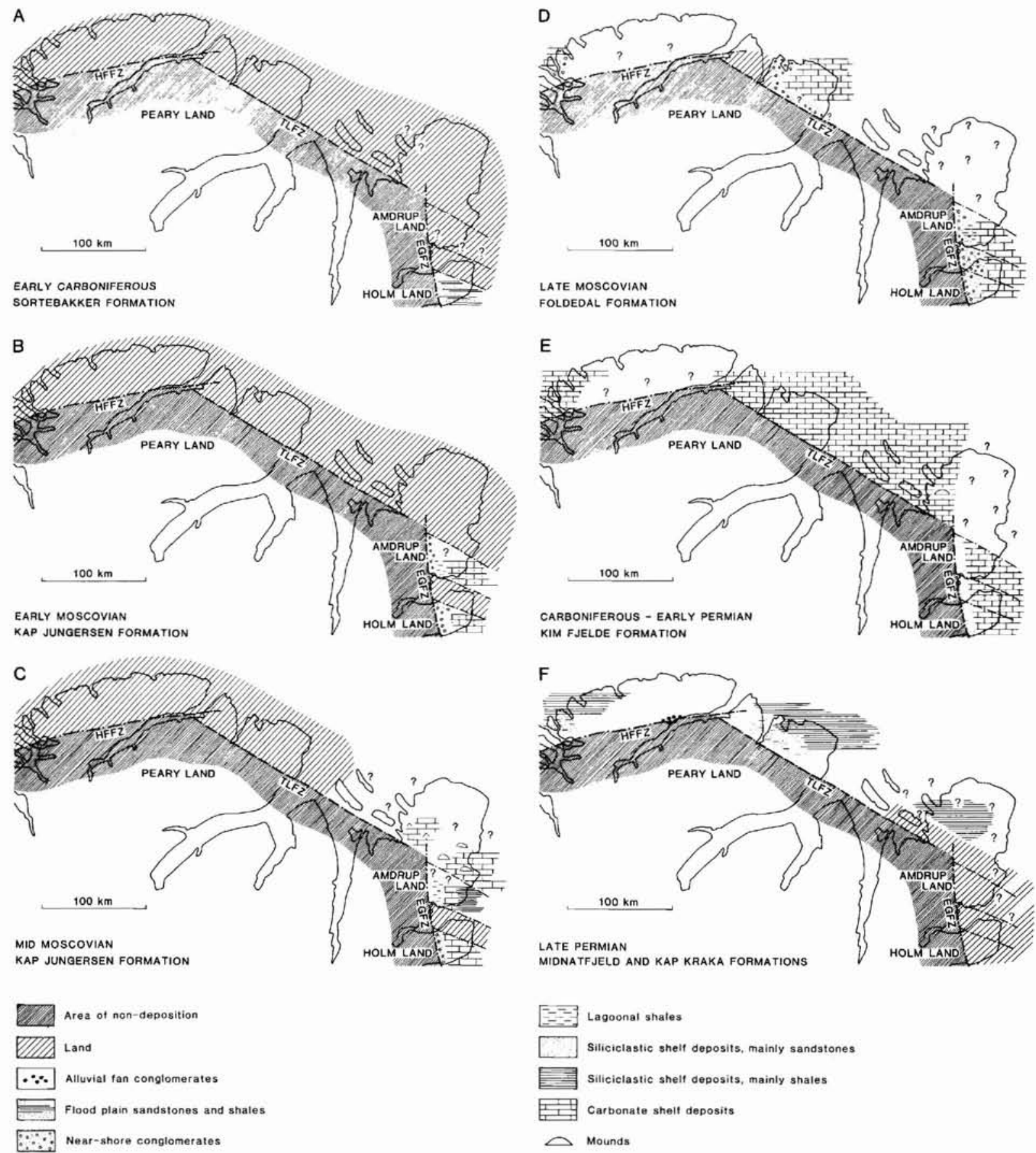

Fig. 4. Palaeogeographic maps and facies patterns during: A, early Carboniferous; B, early Moscovian; C, mid Moscovian; D, late Moscovian; E, latest Carboniferous - Early Permian; F, Late Permian (from Stemmerik \& Håkansson, 1989). HFFZ, Harder Fjord Fault Zone; TLFZ, Trolle Land Fault Zone; EGFZ, East Greenland Fault Zone. 


\section{Basin evolution}

\section{Early Carboniferous (Visean?) fluviatile sedimentation}

Prior to the early Moscovian transgression a thick succession of fluviatile sediments (Sortebakker Formation) accumulated on the southern Holm Land block (Fig. 4A). This more than $600 \mathrm{~m}$ thick succession consists of stacked, fining-upward cycles of flood-plain origin (Hảkansson \& Stemmerik, 1984). A low angle unconformity divides the sediments into a lower shaly unit with mainly thin cycles, and an upper sandy unit with thick cycles (Fig. 5).

The sandy unit includes more than 40 cycles which may be traced laterally for several kilometres (Fig. 5). Each cycle has an erosional lower surface overlain by 3-7 $\mathrm{m}$ thick sandstones showing a variety of stream generated structures indicating easterly palaeocurrents. The fine-grained part of each cycle is composed of carbonaceous shale and occasional thin coal beds containing a sparse macroflora of early Carboniferous age (Nathorst, 1911).

\section{Late Carboniferous cyclic shelf sedimentation}

The early Moscovian - Gzelian Kap Jungersen and Foldedal Formations consist of shelf sediments deposited in two major fining-upward megacycles $170-400 \mathrm{~m}$ thick (Fig. 3). Early Moscovian shelf sedimentation was confined to the southern Holm Land and the Amdrup Land blocks (Figs 4B, C). In contrast late Moscovian Gzelian shelf sedimentation was far more widespread covering Holm Land, southern Amdrup Land, most of
Peary Land and possibly also Prinsesse Ingeborg Halvø (Fig. 4D).

\section{Early Moscovian transgression and shelf sedimentation}

The base of the early Moscovian transgressive succession is exposed along the south coast of Holm Land. Prior to the transgression, the Lower Carboniferous sediments were disturbed along N-S trending faults and subsequently eroded (Fig. 5; Hảkansson et al., 1981).

During the initial stages of the transgression conglomerates and coarse-grained sandstones accumulated in high energy, coastal environments towards the west (Fig. 4B). As the sea-level rose, the conglomerates gradually migrated further westwards forming a wedgeshaped body. Seawards, towards the east, thick deposits of shelf sediments accumulated (Fig. 4B). In southern Holm Land the early stages of shelf sedimentation were dominated by sheet-like bodies of alternating cross-bedded, immature sandstone and biogenic limestone, predominantly wackestone. The limestones yield a normal marine fauna dominated by brachiopods, bryozoans. corals and fusulinids. Occasionally, chaetetids form small patch-reefs, but otherwise reef development is not indicated (Stemmerik, 1989b). In contrast the sandstones only contain a limited fauna of mainly gastropods.

The regular occurrence of normal marine fossils in the sandstones indicates that also this phase of the cycles was marine. The large areal extent of individual beds (Fig. 6) and the almost complete lack of siliciclastic material in the limestones suggest that the cyclicity was caused by very rapid changes in depositional conditions

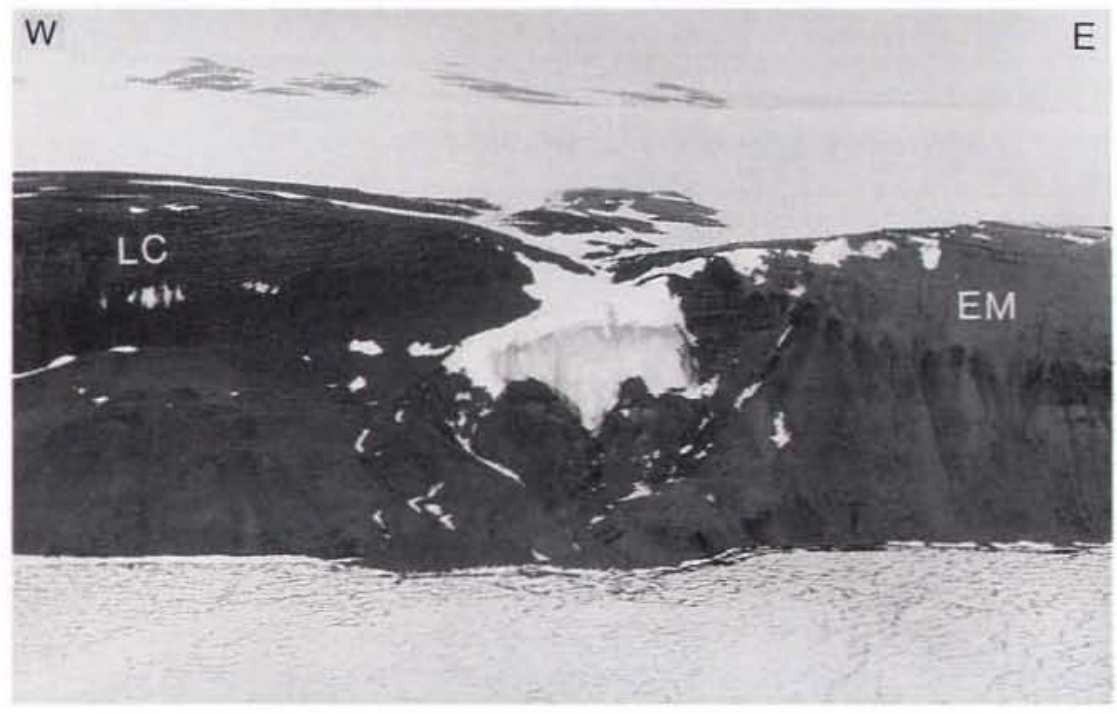

Fig. 5. Lower Carboniferous (LC) fining upward cycles of flood-plain origin unconformably overlain by marine lower Moscovian sediments (EM). Cliff height approximately $350 \mathrm{~m}$, southern Holm Land. 


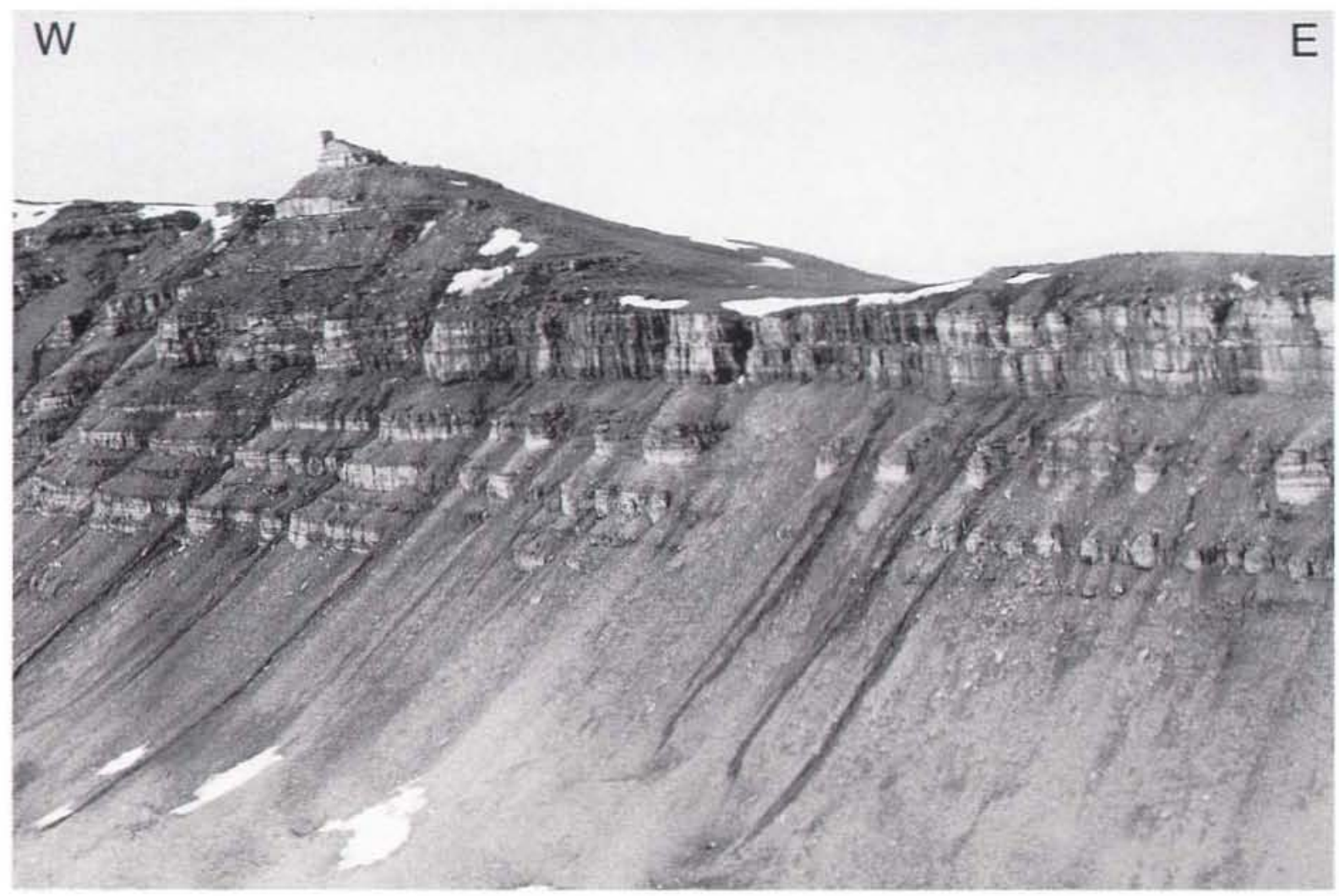

Fig. 6. Interbedded biogenic limestones and sandstones of the Kap Jungersen Formation (lower Moscovian), Exposed section approximately $100 \mathrm{~m}$, southern Holm Land.

over wide areas of the shelf rather than by facies progradation. Gradually, sandstone intervals became less frequent and the upper part of the Kap Jungersen Formation is composed almost exclusively of bedded biogenic limestone (Fig. 4C).

In southern Amdrup Land the succession exhibits a more complex facies pattern (Figs 4B, C). The initial transgressive deposits are not exposed; the oldest sediments are cyclically-interbedded sandstones, shales and biogenic limestones of lagoonal origin. Above follows a thick succession of shelf limestone which is highly fossiliferous in the lower part. Typically, these limestones are overlain by shales but, locally, limestone deposition continued and developed into a 1-2 km wide, N-S trending carbonate platform (Fig. 7). Initially, mainly hypersaline, chert-rich dolomite accumulated producing a platform with up to $50 \mathrm{~m}$ of relief (Fig. 7). Afterwards small bryozoan-crinoid mounds grew on top of the platform at the same time as shale deposition took place in the surrounding topographic lows (Stemmerik, 1989a). Several episodes of sea-level drawdown are suggested to account for the regular occurrence of gypsum beds in the shales and the early vadose diagenetic alteration of the lower part of the mounds. Finally, the entire southern Amdrup Land area became a site of gypsum deposition.

The thick succession of poorly dated, Moscovian bryozoan-dominated mounds and associated carbonates in northern Amdrup Land is believed to be the northwards continuation of this mid-Moscovian platform. There is no evidence of evaporite deposition in northern Amdrup Land, but diagenetic studies of the mounds suggest that they have been subjected to subaerial exposure (Stemmerik, in press).

\section{Late Moscovian - Gzelian shelf sedimentation}

During late Moscovian times the sea transgressed over northern Holm Land and most of the eastern Peary Land blocks (Fig. 4D). The transgression was apparently closely related to tectonic activity along the East Greenland, Trolle Land and Harder Fjord Fault Zones (Hảkansson \& Stemmerik, 1984) and thick wedges of conglomerates were deposited in the newly transgressed areas (Fig. 4D). The input of siliciclastic material was gradually reduced and cyclic sandstone and biogenic 


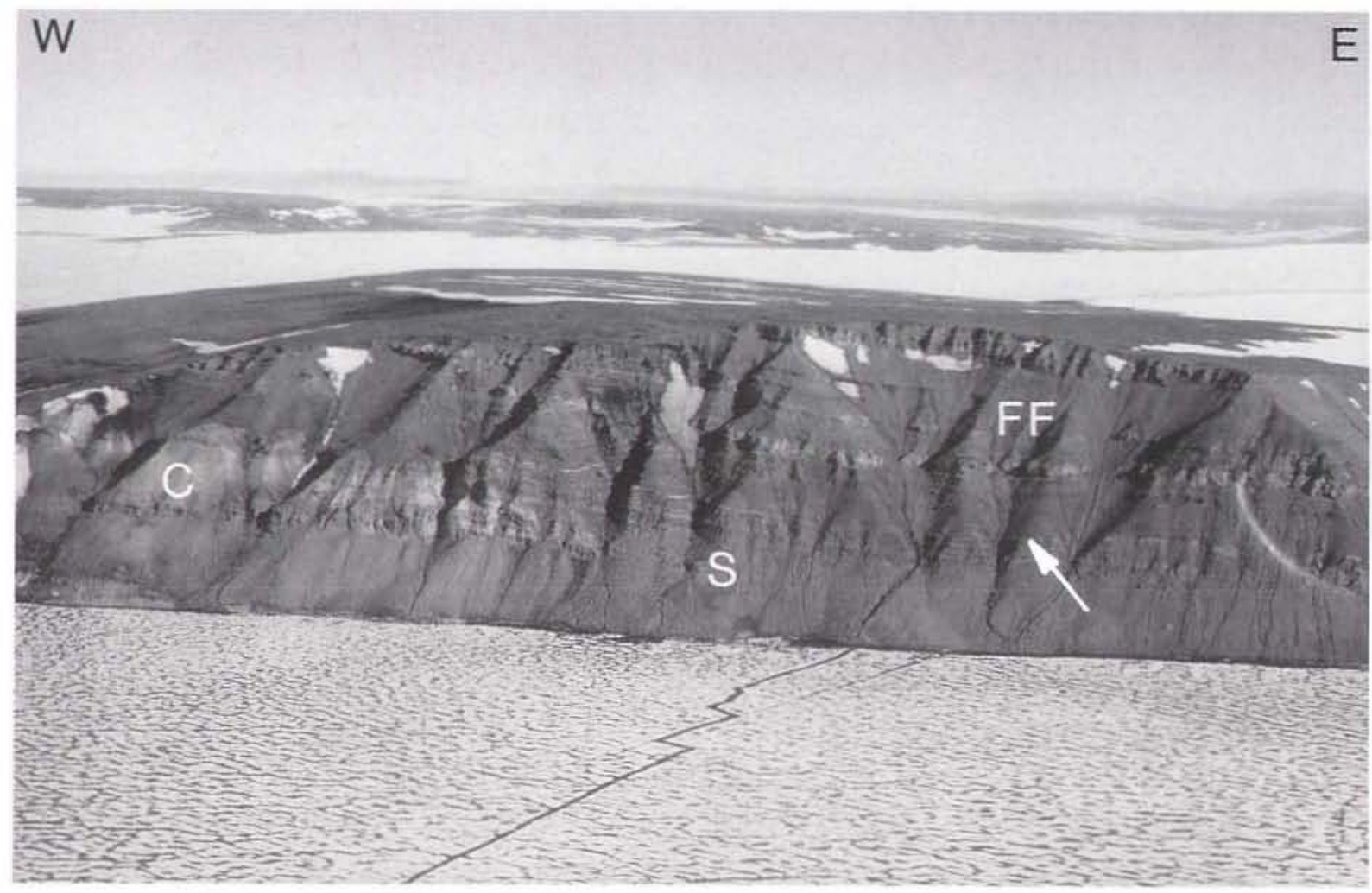

Fig. 7. The early Moscovian - Gzelian succession in southern Amdrup Land. Note the isolated carbonate platform (C) surrounded by shales (S) also belonging to the Kap Jungersen Formation (lower Moscovian). The transition to the overlying Foldedal Formation (FF) (upper Moscovian - Gzelian) is placed at a thick sandstone above the uppermost gypsum layer (arrow). Cliff height approximately $350 \mathrm{~m}$.

limestone were deposited in Holm Land and most of eastern Peary Land (Figs 4D, 8). However, depositional environments is southern Amdrup Land continued to differ from the regional pattern also during the late Moscovian, and deposition of interbedded sandstone, shale and biogenic limestone in quieter, lagoonal environments was re-established. Repeated emergence of the upper part of the succession is indicated both by layers of chicken-wire anhydrite and by abundant levels of shrinkage cracks in the fine-grained siliciclastic sediments.

\section{Late Carboniferous - Early Permian (Kungurian) transgression and carbonate shelf sedimentation}

The Moscovian-Gzelian mixed siliciclastic and carbonate deposits were succeeded in the latest Carboniferous by widespread, rather uniform deposition of shallow water carbonates (Fig. 9). This change was most likely related to a eustatic rise in sea-level.
Well-bedded biogenic limestones are widespread throughout Holm Land, southern Amdrup Land and Peary Land (Fig. 4E). Well preserved macrofossils are rare in these deposits which are mainly composed of fine-grained fragments of brachiopods, bryozoans and crinoids in a micritic matrix. Shallow, more agitated conditions prevailed on the Prinsesse Ingeborg Halvø block where highly fossiliferous wackestones and packstones accumulated.

Sediments from the latest part of the Early Permian (Kungurian) have been recognised only from Peary Land, Prinsesse Ingeborg Halvø and southern Amdrup Land. In Amdrup Land an overall shallowing took place during the Early Permian, and the Kungurian? part of the succession is dominated by highly diverse in situ accumulations of brachiopods and bryozoans in a micritic matrix (Madsen \& Håkansson, 1989). In Peary Land and on Prinsesse Ingeborg Halvø, on the other hand, the depositional environment apparently became gradually deeper during the Early Permian. 


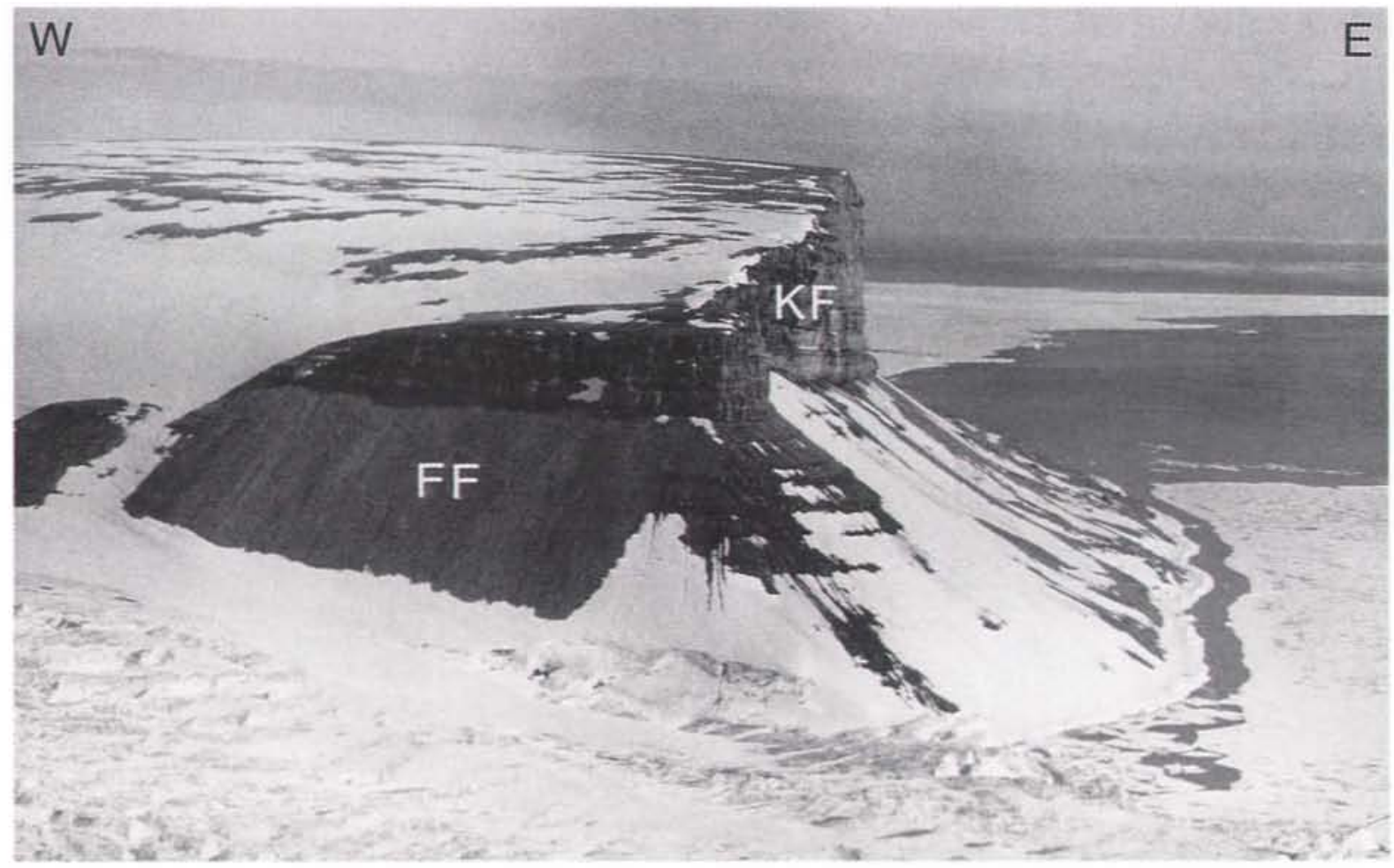

Fig. 8. Interbedded biogenic limestones and sandstones of the Foldedal Formation (FF) (upper Moscovian - Gzelian) overlain by bedded biogenic limestones of the Kim Fjelde Formation (KF). Cliff height approximately $350 \mathrm{~m}$, eastern Holm Land.

Fig. 9. Bedded biogenic limestones of the Kim Fjelde Formation. Exposed section approximately $50 \mathrm{~m}$, southern Amdrup Land.

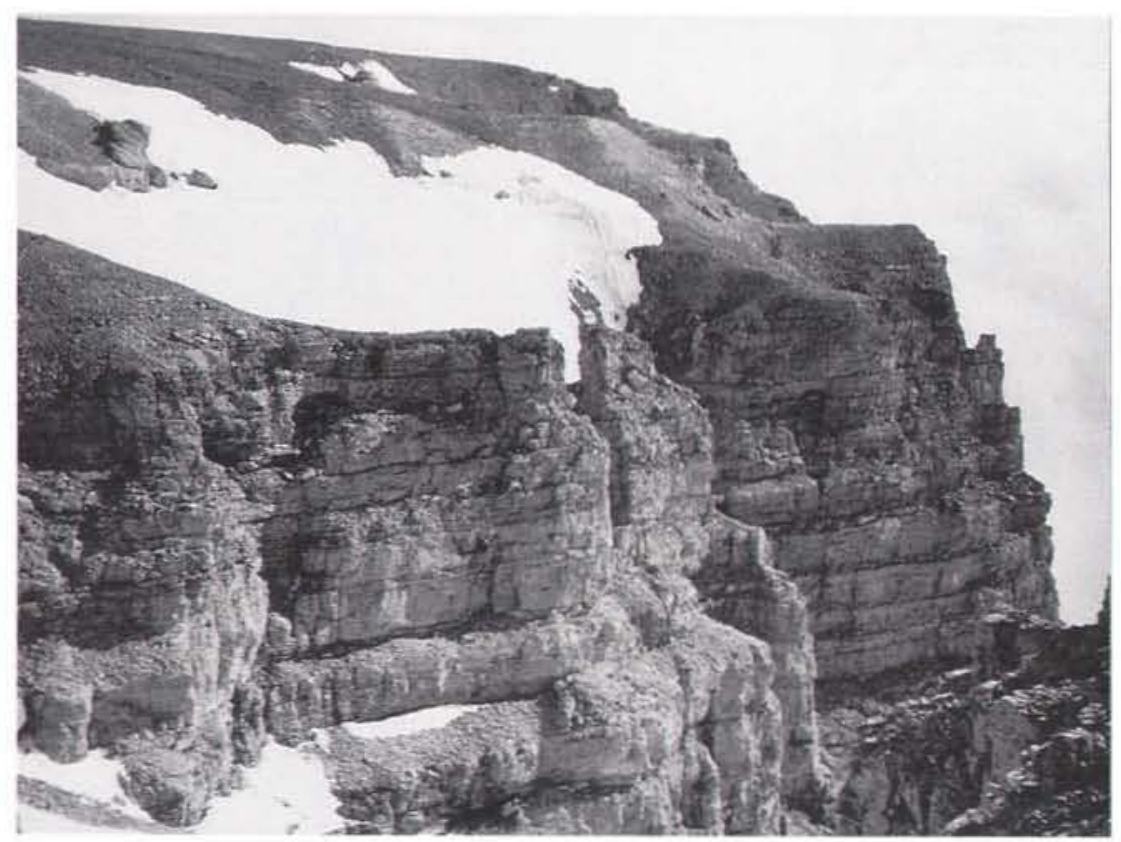




\section{Late Permian siliciclastic shelf sedimentation}

The widespread mid-Permian tectonic event, recognised from central East Greenland, Bjørnøya and Spitzbergen (Worsley \& Edwards, 1976; Steel \& Worsley, 1984; Surlyk et al., 1986), is recorded in Peary Land and on Prinsesse Ingeborg Halvø by renewed influx of siliciclastic material.

The Early Permian deep carbonate shelf now became dominated by shale and chert deposition (Fig. 4F). Gradually, during the Late Permian, an overall regression changed the sedimentation pattern in Peary Land and sandstones prograded across the shelf. As a result the latest part of the succession in Peary Land is dominated by shallow marine sandstones with a few interbeds of biogenic limestone. On Prinsesse Ingeborg Halvø two shallowing upward sequences are recorded; each sequence, $1000-1200 \mathrm{~m}$ thick, comprises a lower basinal shale overlain by shallow water carbonate deposits (Håkansson et al., 1989; Fig. 3).

Further evidence of mid-Permian tectonic activity is recorded along the Harder Fjord Fault Zone where thick wedges of Upper Permian conglomerates, sandstones and carbonaceous shales were deposited locally in fault-bound freshwater basins (Håkansson \& Pedersen, 1982; Wagner et al., 1982).

\section{Sequence correlation}

The Upper Palaeozoic succession in North Greenland can be divided into a number of transgressive-regressive sequences believed to reflect second-order sea-level fluctuations. Major boundaries (sea-level lowstands) are recorded in the mid-Moscovian, latest Gzelian (Carboniferous-Permian boundary), Kungurian-Ufimian boundary and near the Kazanian-Tatarian boundary (Stemmerik \& Worsley, 1989). An additional Late Permian transgressive-regressive sequence is recorded on Prinsesse Ingeborg Halvø, but the more precise age of this sequence is yet unknown (Fig. 3).

The North Greenland depositional sequences show good overall correlation to the sequences in Svalbard (Stemmerik \& Worsley, 1989). Correlation to the depositional sequences, recorded by Beauchamp et al., (1989) in the Sverdrup Basin, is less well established. Co-occurring sea-level lowstands appear to occur near the Carboniferous-Permian boundary, at the Kungurian-Ufimian boundary and possibly near the KazanianTatarian boundary.

Acknowledgements. We wish to thank V. Hermansen, N. Turner, J. Lautrup and B. S. Hansen for technical assistance.

\section{References}

Beauchamp, B., Harrison, J. C. \& Henderson, C. M. 1989: Upper Palaeozoic stratigraphy and basin analysis of the Sverdrup Basin, Canadian Arctic Archipelago: Part 2, transgressive-regressive sequences. Pap. geol. Surv. Can. 89-1G, 115-124.

Bendix-Almgreen, S. E. 1975: Fossil fishes from the marine Late Paleozoic of Holm Land - Amdrup Land, North-East Greenland. Meddr Grønland 195(9), 38 pp.

Davies, G. R. \& Nassichuk, W. W. in press: Carboniferous and Permian history of the Sverdrup Basin, Arctic Islands. In Trettin, H. P. (ed.) The Innuitian region. The geology of North America E, Ottawa: Geol. Survey Canada.

Dawes, P. R. 1976: Precambrian to Tertiary of northern Greenland. In Escher, A. \& Watt, W. S. (ed.) Geology of Greenland, 248-303. Copenhagen: Geol. Surv. Greenland.

Dunbar, C. O. 1962: Faunas and correlation of the Late Paleozoic rocks of Northeast Greenland. Part III. Brachiopoda. Meddr Grønland 167(6), 14 pp.

Dunbar, C. O., Troelsen, J. [C.], Ross, C., Ross, J. P. \& Norford, B. 1962: Faunas and correlation of the Late Paleozoic rocks of Northeast Greenland. Part I. General discussion and summary. Meddr Grønland 167(4), $16 \mathrm{pp}$.

Frebold, H. 1950: Stratigraphie und Brachiopodenfauna des marinen Jungpalaeozoikums von Holms und Amdrups Land (Nordostgrönland). Meddr Grønland 126(3), $97 \mathrm{pp.}$

Grönwall, K. G. 1916: The marine Carboniferous of NorthEast Greenland and its brachiopod fauna. Meddr Grønland 43(20), 110 pp.

Håkansson, E. 1979: Carboniferous to Tertiary development of the Wandel Sea Basin, eastern North Greenland. Rapp. Grønlands geol. Unders. 88, 73-83.

Håkansson, E. \& Pedersen, S. A. S. 1982: Late Paleozoic to Tertiary tectonic evolution of the continental margin in North Greenland. In Embry A. F. \& Balkwill, H. R. (ed.) Arctic geology and geophysics. Mem. Can. Soc. Petrol. Geol. 8, 331-348.

Håkansson, E. \& Stemmerik, L. 1984: Wandel Sea Basin-The North Greenland equivalent to Svalbard and the Barents Shelf. In Spencer, A. M. et al. (ed.) Petroleum geology of the North European margin, 97-107. London: Graham \& Trotman for the Norwegian Petroleum Society.

Håkansson, E. \& Stemmerik, L. 1989: Wandel Sea Basin - A new synthesis of the late Paleozoic to Tertiary accumulation in North Greenland. Geology 17, 683-686.

Håkansson, E., Heinberg, C. \& Stemmerik, L. 1981: The Wandel Sea Basin from Holm Land to Lockwood $\emptyset$, eastern North Greenland. Rapp. Grønlands geol. Unders. 106, $47-63$.

Håkansson, E., Madsen, L. \& Pedersen, S. A. S. 1989: Geological investigations of Prinsesse Ingeborg Halv $\emptyset$, eastern North Greenland. Rapp. Grønlands geol. Unders. 145, 113118.

Henriksen N. \& Higgins, A.K. 1991: The North Greenland Project. Bull. Grønlands geol. Unders. 160 (this volume).

Higgins, A. K., Soper, N. J. \& Friderichsen, J. D. 1985: North Greenland fold belt in eastern North Greenland. In Gee, D. 
G. \& Sturt, B. A. (ed.) The Caledonide orogen - Scandinavia and related areas, 1017-1029. New York: John Wiley \& Son Ltd.

Hurst, J. M., Jepsen, H. F., Kalsbeek, F., McKerrow, W. S., \& Peel, J. S. 1985: The geology of the northern extremity of the East Greenland Caledonides. In Gee, D. G. \& Sturt, B. A. (ed.) The Caledonide orogen - Scandinavia and related areas, 1047-1063. New York: John Wiley \& Son Ltd.

Madsen, L. \& Hăkansson, E. 1989: Upper Palaeozoic bryozoans from the Wandel Sea Basin, North Greenland. Rapp. Grønlands geol. Unders. 144, 43-52.

Nathorst, A. G. 1911: Contributions to the Carboniferous flora of Northeastern Greenland. Meddr Grønland 43(12), 34 pp.

Nilsson, I., Håkansson, E., Madsen, L., Pedersen, S. A. S. \& Stemmerik, L. 1991: Stratigraphic significance of new fusulinid samples from the Upper Palaeozoic Mallemuk Mountain Group, North Greenland. Rapp. Grønlands geol. Unders. 150, 29-32.

Peel, J. S., Dawes, P. R. \& Troelsen, J. C. 1974: Notes on some Lower Palacozoic to Tertiary faunas from eastern North Greenland. Rapp. Grønlands geol. Unders. 65, 18-23.

Petryk, A. A. 1977: Upper Carboniferous (Late Pennsylvanian) microfossils from the Wandel Sea Basin, Peary Land, eastern North Greenland. Rapp. Gronlands geol. Unders. 85, 16-21.

Ross, C. \& Dunbar, C. O. 1962: Faunas and correlation of the Late Paleozoic rocks of Northeast Greenland. Part II. Fusulinidae. Meddr Grønland 167(5), 55 pp.

Ross, J. P. \& Ross, C. 1962: Faunas and correlation of the Late Paleozoic rocks of Northeast Greenland. Part IV. Bryozoa. Meddr Grønland 167(7), 65 pp.

Steel, R. J. \& Worsley, D. 1984: Svalbard's post-Caledonian strata - an atlas of sedimentational patterns and palaeogeographic evolution. In Spencer, A. M. et al. (ed.) Petroleum geology of the North European margin, 109-135. London: Graham \& Trotman for the Norwegian Petroleum Society. Stemmerik, L. 1989a: Crinoid-bryozoan reef mounds, Upper Carboniferous, Amdrup Land, eastern North Greenland. In Geldsetzer, H. H. J., James, N. P. \& Tebbutt, G. E. (ed.)
Reefs - Canada and adjacent areas. Mem. Can. Soc. Petrol. Geol. 13, 690-693.

Stemmerik, L. 1989b: Chaetetid bioherm, Upper Carboniferous, Holm Land, eastern North Greenland. In Geldsetzer, H. H. J., James, N. P. \& Tebbutt, G. E. (ed.). Reefs Canada and adjacent areas. Mem. Can. Soc. Petrol. Geol. 13, 688-689.

Stemmerik, L. in press: Moscovian bryozoan dominated buildups, northern Amdrup Land, eastern North Greenland. In Vorren, T. O. et al. (ed.) Arctic geology and petroleum potential. Amsterdam: Elsevier.

Stemmerik, L. \& Håkansson, E. 1989: Stratigraphy and depositional history of the Upper Palaeozoic and Triassic sediments in the Wandel Sea Basin, central and eastern North Greenland. Rapp. Gronlands geol. Unders. 143, 21-45.

Stemmerik, L. \& Hảkansson, E. 1989: Stratigraphy and depositional history of the Upper Palacozoic and Triassic sediments in the Wandel Sea Basin, eastern North Greenland. Rapp. Gronlands geol. Unders. 143, 21-45.

Stemmerik, L. \& Worsley, D. 1989: Late Palacozoic sequence correlations, North Greenland, Svalbard and the Barents Shelf. In Collinson, J. D. (ed.) Correlation in hydrocarbon exploration, 99-111. London: Graham \& Trotman for the Norwegian Petroleum Society.

Surlyk, F., Hurst, J. M., Piasecki, S., Rolle F., Scholle, P. A., Stemmerik, L. \& Thomsen, E. 1986: The Permian of the western margin of the Greenland Sea - a future exploration target. In Halbouty, M. T. (ed.) Future petroleum provinces of the world. Mem. Am. Ass. Petrol. Geol. 40, 629-659.

Vischer, A. 1943: Dic postdevonische Tektonik von Ostgrönland zwischen $74^{\circ}$ und $75^{\circ}$ N.Br., Kuhn $\varnothing$, Wollaston Forland, Clavering $\varnothing$ und angrenzende Gebiete. Meddr Gronland 133(7), $195 \mathrm{pp}$.

Wagner, R. H., Soper, N. J. \& Higgins, A. K. 1982: A Late Permian flora of Pechora affinity in North Greenland. Rapp. Grønlands geol. Unders. 108, 5-13.

Worsley, D. \& Edwards, M. B. 1976: The Upper Paleozoic succession of Bjørnøya. Norsk Polarinst. Árbok 1974, 17-34. 

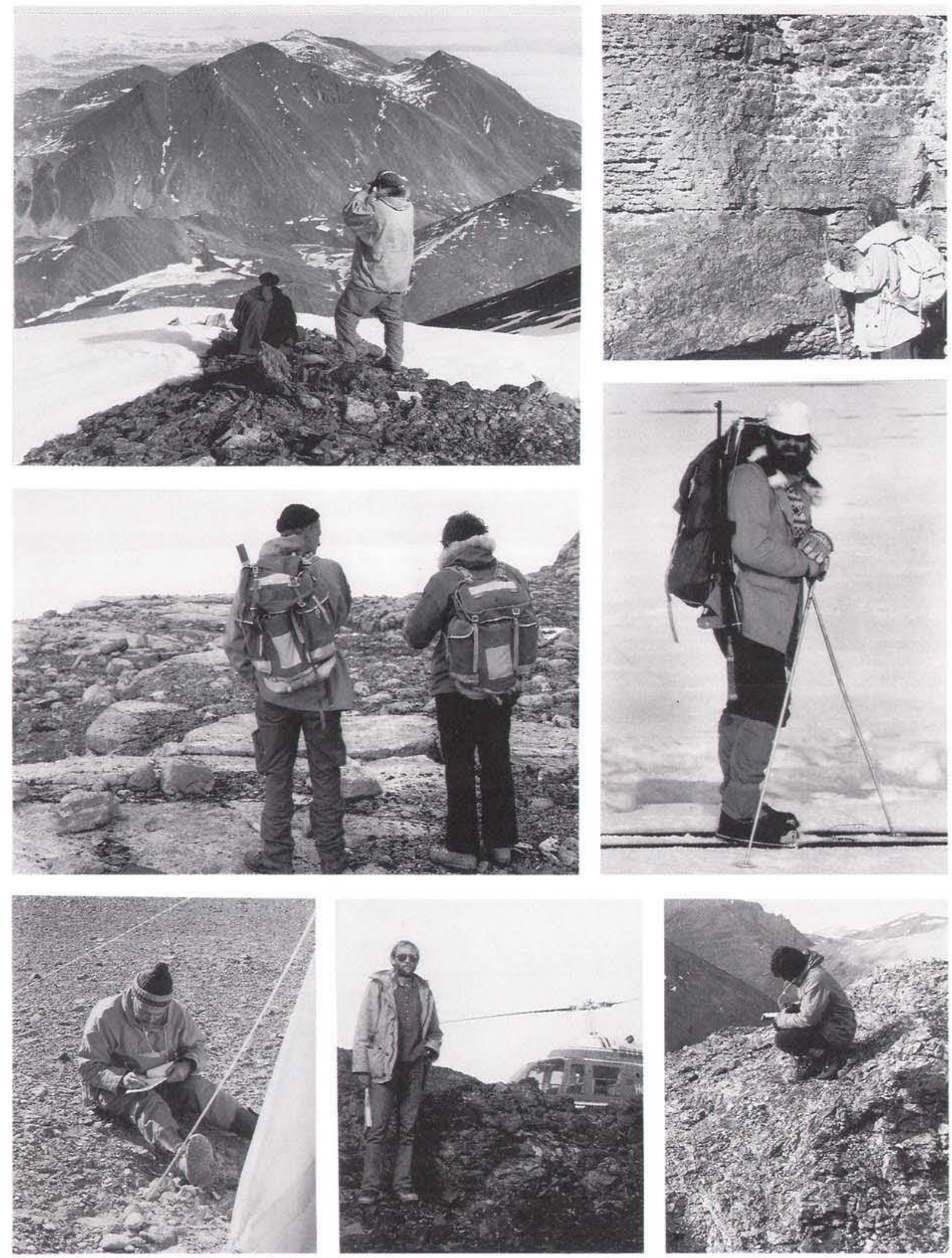

The North Greenland Project: geologists in the field. 